\title{
COMPARISON OF STATOR WINDINGS ON PERMANENT MAGNET GENERATORS FOR HORIZONTAL AXIS WIND TURBINE (HAWT)
}

\author{
Basuki Winarno, Jasa Kusumo Haryo, Yulius Harry Widodo, Imam Basuki
}

\begin{abstract}
The generator is the main component for a wind power plant. The Horizontal Axis Wind Turbine (HAWT) is one of electric power plants types which has a horizontal axis. The plant is suitable to be operated in areas that have a fairly large wind speed. The low-speed HAWT generator can be designed using a permanent magnet. This paper compares the coil design of the stator generator which has 12 poles arranged in 3 phases, and the rotor part consists of 24 Neodymium (NdFeB) type permanent magnets. Based on analytical studies, the design of generator windings is varied by 3 turns and 6 turns. The tests has been carried out for 100 rpm 1000rpm generator rotation. The research conclusions are recommendations to reduce 0.5 times the rotation and at 3 times the winding in obtaining optimal performance.
\end{abstract}

Index Terms - stator winding, permanent magnet, generator, HAWT.

\section{INTRODUCTION}

$\mathrm{P}$ OWER Generators Wind tubine is a power plant that utilizes wind as the main energy source to drive a mill (angina turbine). The kinetic energy produced by the wind turbine is converted into mechanical energy that will rotate the generator and will generate electrical energy. The axial flux type machine uses a permanent magnet that has a lightweight, disc-shaped construction, and has a large power density. The use of a permanent magnet on this electric machine can produce a magnetic field in the air gap without the need for excitation and without electric power dissipation[1]. The working principle of the generator uses the principle of Faraday's experiment, ie, rotating the magnet in the coil or vice versa, when the magnet is moved in the coil, the magnetic force flux changes (changes in the direction of magnetic field spread) inside the coil and penetrates

Basuki Winarno Lecturer in Electrical Engineering- Engineering Department State Polytechnic of Madiun, Madiun, Indonesia (email: basuki@pnm.ac.id)

Jasa Kusumo Haryo Lecturer in Electrical EngineeringEngineering Department State Polytechnic of Madiun, Madiun, Indonesia (email: jasakusumo@pnm.ac.id)

Yulius Harry Widodo Lecturer in English Department State Polytechnic of Madiun, Madiun, Indonesia (email: yulius@pnm.ac.id)

Imam Basuki Lecturer in automotive Engineering- Engineering Department State Polytechnic of Madiun, Madiun, Indonesia(email: imam_yb@pnm.ac.id) perpendicular to the coil causing a potential difference between the ends end of the coil [2]. The main requirement to generate a potential difference is that there must be a change in magnetic flux, otherwise, there will be no electricity. When the magnet is moved near the coil electromagnetic force will appear on the coil. The direction of the voltage generated when the magnet moves closer or away from the coil is also opposite. The amount of voltage to be generated will increase as the magnetic force increases and the speed of the magnetic motion. In addition, the generated voltage also increases when the number of coils is increased[3].

\section{DESIGN GENERATOR}

The wind power plant works by getting energy from the wind that turns the turbine connected to the gearbox. The gearbox rotates the generator so that it produces a voltage which is subsequently rectified using the rectifier [4]. Because the voltage is not stable so it needs a buck-boost converter circuit that will raise and lower the voltage. The stable voltage is used to charge the batteries. Next accumulator is connected to the inverter which will convert the dc voltage to ac. The system block diagram is shown in Fig. 1.

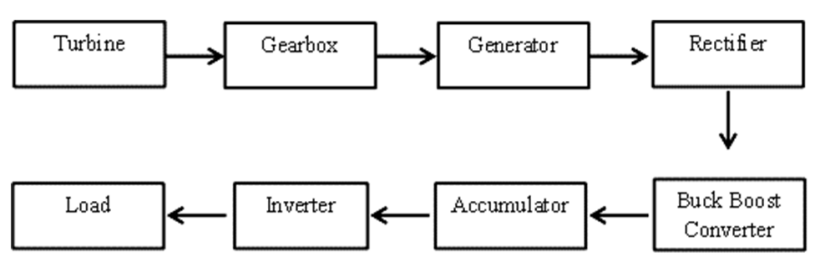

Fig 1. Block Diagram System.

The design of the number of generator poles in each rotor with a frequency determined $50 \mathrm{~Hz}$ and rotational speed generator of 500rpm with equation 1 .

$$
f=\frac{p}{2} \times \frac{n}{60}
$$

With $\mathrm{n}$ is the rotational speed of the rotor (Rpm) and $\mathrm{p}$ is the number of rotor poles, $\mathrm{p}$-value of 12 is obtained. Design rotor with calculate the distance between magnets using equation 2 . 


$$
T f=\sin 30^{\circ} \times b
$$

With $T f$ is the distance between magnets $(\mathrm{cm})$ and $\mathrm{b}$ is the magnetic length $(\mathrm{cm})$, the distance between magnets is $2.5 \mathrm{~cm}$. The distance between these magnets is used to search the circumference of the rotor[5]. Calculation of rotor circumference using equation 3.

$$
K r=(T f \times p)+(a \times p)
$$

With $K r$ is the circumference of the rotor $(\mathrm{cm})$ and a is the magnetic width $(\mathrm{cm}), \mathrm{Kr}$ value of $45 \mathrm{~cm}$ is obtained.

The calculation of the magnetic area is used to determine the area of the rotor disk since the area of the stator disk must be in accordance with the area of the rotor disk[6]. Calculation of area of magnet area using equation 4.

$$
\text { Amagn }=\frac{\pi \cdot\left(r_{0^{2}}-r_{i^{2}}\right)-T f \cdot\left(r_{0}-r_{i}\right)}{N m}
$$

With ro represents the magnetic outer radius, ri represents the radius of the magnet and $\mathrm{Nm}$ is the number of magnets, the magnitude area of $6.0625 \mathrm{~cm}^{2}$ is obtained[7]. Calculation of magnetic flux density using equation 5 .

$$
\beta \max =\operatorname{Br} \cdot \frac{\operatorname{Im}}{\operatorname{Im} \cdot \delta}
$$

With $B r$ is the magnetic flux density (Tesla), Im is the magnetic thickness $(\mathrm{cm})$ and $\delta$ is the distance between the rotor and the stator $(\mathrm{cm})$, the magnitude of the magnetic [8] flux density $(\beta m a x)$ is 6.05T. Calculation of magnetic flux density using equation 6

$$
\Phi_{\max }=A_{\text {magn }} \cdot \beta_{\text {max }}
$$

Magnetic flux density $\left(\Phi_{\max }\right)$ was obtained at 0.0003940625 Webber

Stator design is used to determine the number of windings used in one coil. The number of coils 12 pieces, this value is known from the number of magnets on the rotor so that the coils can fully obtain the magnetic field[9]. Calculation of the number of windings using equation 7 .

$$
\text { Erms }=\frac{2 \pi}{\sqrt{2}} \cdot N \cdot f \cdot \Phi_{\max } \cdot \frac{N s}{N p h}
$$

With Erms is the induced voltage (volts), $N$ is the number of windings, $N s$ is the number of coils and $N p h$ is the number of phases, obtained The number of windings $(N)$ of 34 coils.

Based on the calculation, construction of generator with the height of skeleton $25 \mathrm{~cm}$ and width $20 \mathrm{~cm}$. For bearing has an outer diameter of $3 \mathrm{~cm}$ and an inner diameter of $1 \mathrm{~cm}$ then used as well as a diameter of 1 $\mathrm{cm}$. The generator construction is shown in Figures 2 and 3

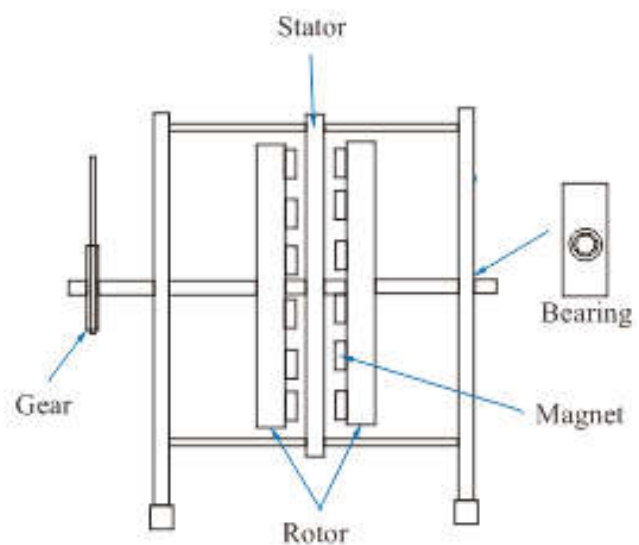

Fig 2. Construction generator.

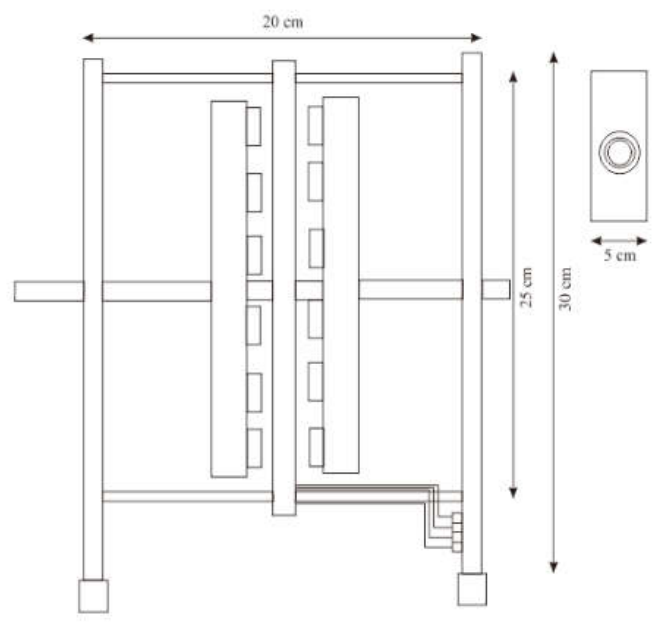

Fig 3. Generator size.

Copper wire used as a stator coil forming is $0.5 \mathrm{~mm}$ in size with a current carrying capability of 0.390 to 0.588 Ampere. At the stator, a rectifier or rectifier is installed which functions as an AC (Alternate Current) signal to a DC (Direct Current) signal[10]. This Rectifier or Wave Rectifier circuit generally uses a Diode as its Main Component. This is because diodes have characteristics that only pass electric current in one direction and inhibit electric current from the opposite direction. If a Diode is alternating current (AC), then the Diode will only pass half the wave, while the half wave will be blocked[11]. Full Wave Rectifier using 4 Diodes is a type of Rectifier that is most often used in a Power Supply circuit because it provides better performance than other types of rectifiers[12]. Full Wave Rectifier is also often referred to as Bridge Rectifier or Rectifier Bridge. The rectifier circuit used is shown in Figure 4. 


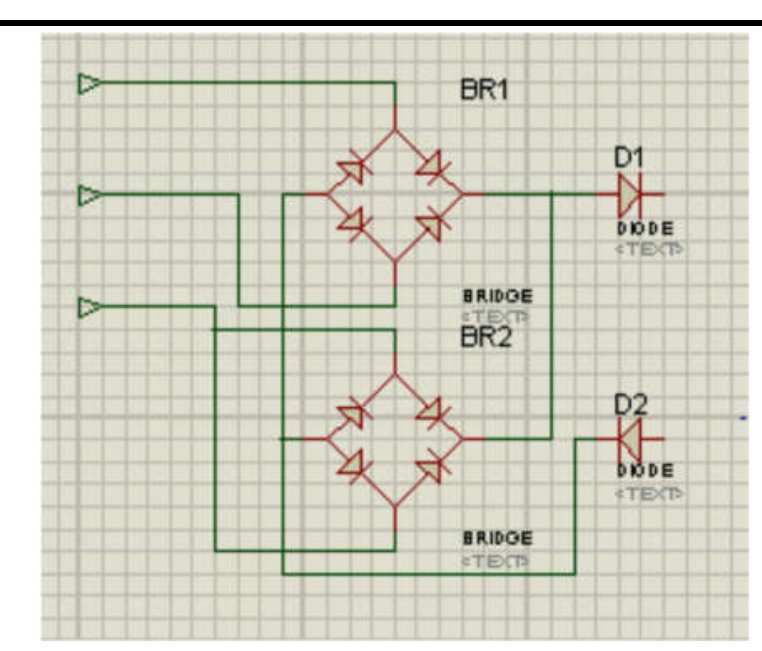

Fig 4. Rectifier circuit.

\section{EXPERIMENT RESULT}

At the time of testing, the coil with the amount of 34 windings did not produce a voltage, so in the next test added the number of windings to 102 windings and 204 turns. Installation of a generator with a supporting iron is shown in Figure 5 and the installation of the generator after being connected to the gearbox is shown in Figure 6.

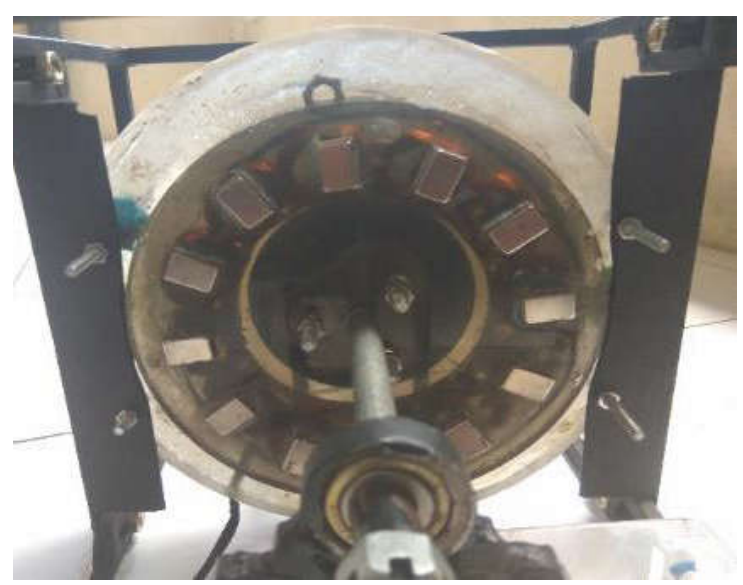

Fig 5. Generator.

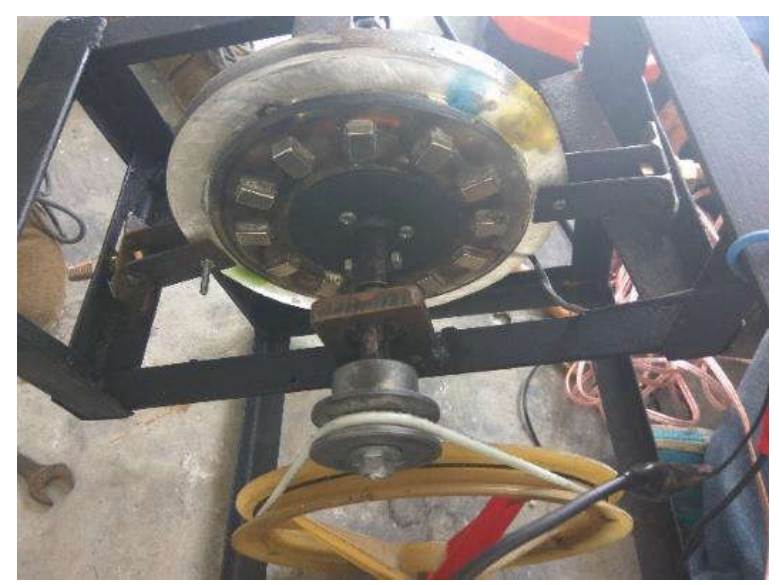

Fig 6. Generator with Gearbox.

Generator testing is done by rotating the rotor using a rotary auxiliary so that the rotation speed of the rotor can be measured. The test is done by altering the coil on the stator according to the calculation and adding the number of windings as much as $3 x$ perculation and $6 \mathrm{x}$ calculation.

TABLE I

GENERATOR TEST

\begin{tabular}{ccccc}
\hline \hline No & Rpm & $\begin{array}{c}\text { 34 loops of } \\
\text { wire (Volt) }\end{array}$ & $\begin{array}{c}\text { 102 loops of } \\
\text { wire (Volt) }\end{array}$ & $\begin{array}{c}\text { 204 loops of } \\
\text { wire (Volt) }\end{array}$ \\
\hline 1 & 100 & 0,01 & 1,1 & 2,5 \\
2 & 200 & 0,01 & 1,9 & 4,5 \\
3 & 300 & 0,02 & 3 & 5 \\
4 & 400 & 0,03 & 4,3 & 8,6 \\
5 & 500 & 0,03 & 5,8 & 10,1 \\
6 & 600 & 0,05 & 6,9 & 12,3 \\
7 & 700 & 0,06 & 7,8 & 15,2 \\
8 & 800 & 0,09 & 11 & 19 \\
9 & 900 & 0,11 & 15,3 & 24,7 \\
10 & 1000 & 0,14 & 17,4 & 29,5 \\
\hline \hline
\end{tabular}

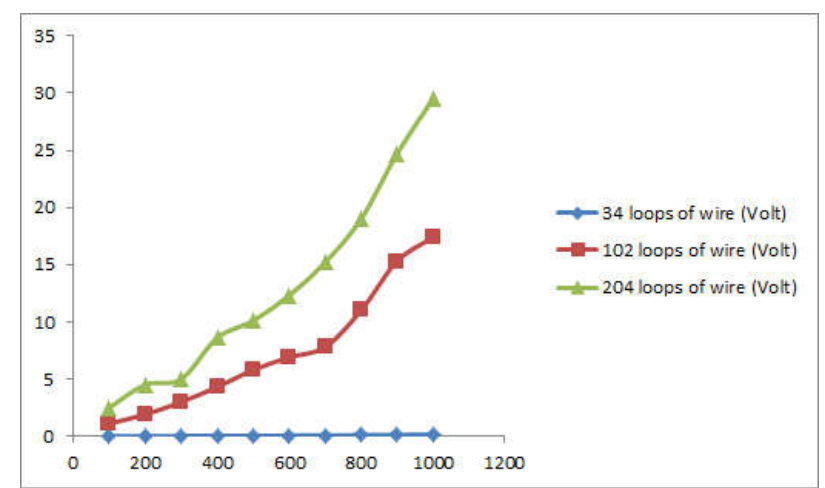

Fig 7. Result Test.

In the first test, the stator coil corresponds to a calculation of 34 loops resulting in a very small amount. In the second test, the amount of stator coil windings is raised $3 \mathrm{x}$ to 102 windings. At $500 \mathrm{rpm}$ rotation, the generator produces a voltage of 5.8 volts. After the rotation of the rotor is increased $2 \mathrm{x}$ by $1000 \mathrm{rpm}$, the generator produces a voltage of 17.4 volts. In the third test, the amount of stator coil windings is increased $6 \mathrm{x}$ to 204 turns. At $500 \mathrm{rpm}$ rotation produces a voltage of 10.1 volts. Then after the rotation of the rotor is increased $2 \mathrm{x}$ to $1000 \mathrm{rpm}$, the generator produces a voltage of 29.5 volts. Test results show that the number of stator windings and the number of rotation of the rotor is very influential on the generator output.

\section{CONCLUtion}

Permanent magnet generator can be used for HAWT type wind power. However, at the time of design, to obtain the output generator that can be used for the charge must take into account the wind speed in the area of the prospective installation of power plants. Generator making can be done by increasing the number of loops in the stator coil at least $2 \mathrm{x}$ from the calculation 
because the output of the generator is not stable depending on wind speed. While the calculation of the rotation of the rotor should be reduced $0.5 \mathrm{x}$. The calculation results with rotor rotation of $500 \mathrm{rpm}$, after the test obtained $2 x$ effective round calculation of 1000 rpm. This prototype is ready to be marketed, of course, by fixing the packaging to make it more attractive and look neat

\section{ACKNOWLEDGMENT}

The authors would like to thank the Politeknik Negeri Madiun who have facilitated the infrastructure and Ristekdikti who have provided financial support to this research.

\section{REFERENCES}

[1] Abrar Ridwan, dkk. Pengembangan Generator Mini Dengan Menggunakan Magnet Permanen. (Jakarta: Fakultas Teknik Universitas Indonesia)

[2] Arif, N. 2014. Perancangan Generator Putaran Rendah Magnet Permanen Jenis FE Fluks Aksial (Semarang: Universitas Diponegoro Indonesia)

[3] Dhanar, Y. 2013. Desain Generator Axial Kecepatan Rendah Menggunakan 8 Buah Magnet Permanen Dengan Dimensi $10 \mathrm{x}$ 10 x $1 \mathrm{~cm}$ (Surakarta: Fakultas Teknik Jurusan Elektro, Universiatas Muhammadiyah Indonesia)

[4] Kurt, E., Gör, H., \& Demirtaş, M. (2014). Theoretical and experimental analyses of a single phase permanent magnet generator (PMG) with multiple cores having axial and radial directed fluxes. Energy Conversion and Management, 77, 163172.
[5] Ahmad, G., \& Amin, U. (2017). Design, construction and study of small scale vertical axis wind turbine based on a magnetically levitated axial flux permanent magnet generator. Renewable Energy, 101, 286-292.

[6] Ahmad, G., \& Amin, U. (2017). Design, construction and study of small scale vertical axis wind turbine based on a magnetically levitated axial flux permanent magnet generator. Renewable Energy, 101, 286-292.

[7] Laxminarayan, S. S., Singh, M., Saifee, A. H., \& Mittal, A. (2017). Design, modeling and simulation of variable speed Axial Flux Permanent Magnet Wind Generator. Sustainable Energy Technologies and Assessments, 19, 114-124.

[8] Akello, P. O., Ochieng, F. X., \& Kamau, J. N. (2015). Performance analysis of a direct drive permanent magnet generator for small wind energy applications. Journal of Sustainable Research in Engineering, 1(3), 1-9.

[9] Tripathi, S. M., Tiwari, A. N., \& Singh, D. (2015). Gridintegrated permanent magnet synchronous generator based wind energy conversion systems: A technology review. Renewable and Sustainable Energy Reviews, 51, 1288-1305.

[10] Serrano-González, J., \& Lacal-Arántegui, R. (2016). Technological evolution of onshore wind turbines - a marketbased analysis. Wind Energy, 19(12), 2171-2187.

[11] Teyber, R., Trevizoli, P. V., Christiaanse, T. V., Govindappa, P., Niknia, I., \& Rowe, A. (2017). Permanent magnet design for magnetic heat pumps using total cost minimization. Journal of Magnetism and Magnetic Materials, 442, 87-96.

[12] Fawzal, A. S., Cirstea, R. M., Gyftakis, K. N., Woolmer, T. J., Dickison, M., \& Blundell, M. (2016, September). The fan design impact on the rotor cooling of axial flux permanent magnet machines. In Electrical Machines (ICEM), 2016 XXII International Conference on (pp. 2725-2731). IEEE. 